\title{
Analisis Pengaruh Faktor-Faktor terhadap Income Smoothing dengan Gender sebagai Variabel Moderator pada Emiten Perbankan
}

\author{
Alvinda Kusumaningrostati \\ Departemen Manajemen, Fakultas Ekonomi dan Manajemen \\ Institut Pertanian Bogor \\ Kampus Dramaga Bogor 16680 \\ Ali Mutasowifin \\ Departemen Manajemen, Fakultas Ekonomi dan Manajemen \\ Institut Pertanian Bogor \\ Kampus Dramaga Bogor 16680 \\ e-mail: alimu@ipb.ac.id
}

\begin{abstract}
Management can intervene to the process of preparation of financial statements for external parties by leveling, raising, or lowering the reported profit. One pattern of earnings management is income smoothing, that is leveling reported profit in order to reduce fluctuations of earnings. The purpose of this study is to evaluate whether the factors of Return on Assets (ROA), Debt to Equity Ratio (DER), as well as Net Interest Margin (NIM) affect income smoothing using gender as moderator variable, by observing the proportion of women in boards. The Samples were 26 banks listed on IDX, 2008-2012 period, analyzed by using the SPSS multiple linear regression testing and regression models moderation. We found that ROA, NIM, DER, moderated by gender variable significantlyaffect income smoothing. Partial test also showed that with gender as moderator, ROA and NIM significantly influence income smoothing, while DER has no effect.

Keywords:debt to equity ratio (DER), gender, income smoothing, net interest margin (NIM), return onassets (ROA)
\end{abstract}

\begin{abstract}
ABSTRAK
Manajemen dapat melakukan intervensi dalam proses penyusunan laporan keuangan bagi pihak eksternal dengan cara meratakan, menaikkan, atau menurunkan laba yang dilaporkan. Salah satu pola manajemen laba adalah income smoothing, dengan cara meratakan laba yang dilaporkan sehingga dapat mengurangi fluktuasi laba. Tujuan penelitian ini adalah mengevaluasi faktor-faktor yang diduga mempengaruhi perataan laba dengan menggunakan Return on Assets (ROA), Debt to Equity Ratio (DER), Net Interest Margin (NIM) sebagai variabel bebas dan gender sebagai variabel moderator, untuk mengidentifikasi pengaruh variabel independen terhadap income smoothing dengan memperhatikan proporsi perempuan dalam dewan perusahaan. Sampel penelitian ini adalah 26 bank yang tercatat di BEI periode 2008-2012 dan dianalisis menggunakan SPSS dengan pengujian regresi linier berganda dan model regresi moderasi. Hasil penelitian menunjukkan bahwa secara simultan ROA, NIM, dan DER dengan variabel moderator gender berpengaruh signifikan terhadap income smoothing. Pengujian secara parsial juga menunjukkan ROA dan NIM dengan variabel moderator gender berpengaruh signifikan terhadap income smoothing, sedangkan DER tidak berpengaruh.

Kata kunci: debt to equity ratio (DER), gender, income smoothing, net interest margin (NIM), return on assets (ROA)
\end{abstract}




\section{Pendahuluan}

Laporan keuangan merupakan sarana dalam mengkomunikasikan informasi keuangan, baik kepada pihak internal perusahaan seperti manajemen dan karyawan, maupun pihak eksternal perusahaan seperti investor, kreditur dan pemerintah. Bestivano (2013) menyatakan bahwa salah satu parameter dari laporan keuangan yang digunakan untuk mengukur kinerja manajemen perusahaan adalah laba. Pengukuran laba penting dalam menentukan prestasi perusahaan, sebagai informasi dalam pembagian laba serta penentuan kebijakan investasi. Oleh karena itu, laba menjadi sorotan banyak kalangan, seperti akuntan, pengusaha, analis keuangan, pemegang saham, atau ekonom.

Informasi laba bertujuan untuk menilai kinerja manajemen, membantu mengestimasi kemampuan laba dalam jangka panjang, dan memperkirakan risikorisiko investasi (Pramono 2013). Manajemen perusahaan menyadari, bahwa informasi laba sangat penting dalam menentukan kebijakan penyusunan laporan keuangan untuk mencapai tujuan tertentu dengan pilihan kebijakan akuntansi yang disebut dengan manajemen laba (Djaddang 2010). Manajer melakukan manajemen laba guna mengatasi masalah yang mungkin timbul antara pihak manajemen dengan pihak lain yang berkepentingan dengan perusahaan. Berdasarkan teori keagenan dalam perbankan, industri yang sarat dengan berbagai regulasi, maka pihak manajemen disebut sebagai agent sedangkan pihak lain yang terlibat dalam hubungan keagenan disebut regulator (Rahmawati et al. 2006).

Para praktisi menilai manajemen laba sebagai kecurangan, sementara akademisi menilai sebaliknya. Meskipun demikian, kedua belah pihak menyepakati bahwa manajemen laba adalah upaya untuk mengubah, menyembunyikan, dan menunda informasi keuangan dengan menggunakan metode dan prosedur akuntansi yang diterima dan diakui secara umum (Sulistyanto 2008). Emiten perbankan dituntut memenuhi beragam ketentuan laporan keuangan sesuai Peraturan Bank Indonesia Nomor 13/1/2011 tentang Penilaian Tingkat Kesehatan Bank Umum. Laporan keuangan merupakan sumber informasi yang digunakan dalam menilai kinerja atau tingkat kesehatan perbankan. Hal ini membuat manajer diduga cenderung melakukan manajemen laba agar dapat memenuhi kriteria yang disyaratkan oleh Bank Indonesia (Sari 2012).

Manajemen laba dilakukan dengan banyak bentuk, seperti taking bath, income maximization, income minimization, dan income smoothing. Salah satu bentuk manajemen laba yang menarik untuk diteliti lebih dalam adalah tindakan yang berkaitan dengan income smoothing. Pola tindakan ini paling sering dilakukan untuk mengantisipasi kondisi yang akan dihadapi perusahaan dengan cara meratakan laba yang dilaporkan, sehingga dapat mengurangi fluktuasi laba karena investor lebih menyukai laba yang relatif stabil (Rahmawati 2012).

Beberapa penelitian terdahulu memperlihatkan hasil yang tidak konsisten meski dilakukan pada objek yang sama. Profitabilitas diduga mempengaruhi income smoothing, karena perhatian utama investor pada tingkat profitabilitas perusahaan mendorong manajer untuk melakukan perataan laba. Hal tersebut didukung oleh penelitian Atarwaman (2011) dan Wijaya (2011) yang menyatakan bahwa profitabilitas yang diwakili oleh Return on Assets (ROA) secara parsial berpengaruh terhadap 
kecenderungan praktik perataan laba. Selain itu, penggunaan Net Interest Margin (NIM) sebagai variabel yang mempengaruhi income smoothing didukung oleh penelitian Sari (2012) dan Astuti (2013), dengan NIM sebagai indikator untuk mengukur kemampuan perbankan dalam mengelola aktiva produktifnya dalam menghasilkan pendapatan bunga bersih (Sari 2012).

Sementara itu, Wulandari (2013) dan Masodah (2007) membuktikan bahwa hanya Debt to Equity Ratio (DER) yang berpengaruh signifikan terhadap praktik perataan laba. Berbeda dengan Widaryanti (2009) yang menunjukkan bahwa ukuran perusahaan, profitabilitas, financial leverage, net profit margin dan varian nilai saham tidak terbukti mempengaruhi praktik perataan laba. Hasil ini sama dengan Kurniawan (2012) bahwa net profit margin, leverage, dan profitabilitas tidak berpengaruh terhadap perataan laba.

Besarnya kesempatan dan dorongan bagi manajer untuk melakukan income smoothing mendorong mereka meneliti kembali pentingnya faktor-faktor yang diduga mempengaruhi income smoothing. Berbeda dengan penelitian sebelumnya, penelitian ini menggunakan variabel ROA, NIM, dan DER sebagai variabel independen dan menambahkan gender sebagai variabel moderator selama periode 2008 sampai dengan 2012. Penambahan variabel gender dalam penelitian ini dilandasi pemikiran bahwa gender merupakan salah satu variabel penting yang mempengaruhi proses pengambilan keputusan.

Carter et al. (2003) sering disebut sebagai penyaji pertama dengan bukti empiris tentang apakah keragaman dalam dewan perusahaan berhubungan dengan nilai keuangan yang meningkat. Dalam penelitiannya, keragaman didefinisikan sebagai persentase perempuan, Afro-Amerika, Asia, dan Hispanik dalam dewan perusahaan. Mereka menjumpai hubungan positif yang signifikan antara fraksi perempuan atau minoritas dalam dewan perusahaan dengan nilai perusahaan.

Topik yang dibahas Carter et al. (2003) memperoleh perhatian dan diikuti oleh sejumlah penelitian serupa dengan menggunakan area sampel penelitian spesifik dari seluruh penjuru dunia, misalnya Nigeria (Ujunwa et al. 2012), Selandia Baru (Dunstan et al. 2011 dan Fauzi et al. 2012), Sri Lanka (Wellalage et al. 2013), Amerika Serikat (Carter et al. 2010 dan Colaco et al. 2011), Malaysia (Bolbol I. I. H. 2012), Pakistan (Yasser 2012), Spanyol (Fuentes-Medina et al. 2013), Italia (Schwizer et al. 2012 dan Bianco et al. 2013), Bangladesh (Dutta 2006), dan Inggris Raya (Martin et al. 2009).

Vania dan Supatmi (2014) serta Darmadi (2011) memperpanjang daftar peneliti dengan bahasan gender pada perusahaan-perusahaan di Indonesia. Selain itu, ada pula Jamilah et al. (2007) yang menyebutkan temuan riset literatur psikologis kognitif dan pemasaran, bahwa perempuan diduga lebih efisien dan efektif dalam memproses informasi saat terjadi kompleksitas tugas dalam pengambilan keputusan dibandingkan dengan pria. Hal ini didukung beberapa penelitian terbaru yang dikemukakan oleh IFC (2013), bahwa perusahaan yang memiliki lebih banyak perempuan sebagai anggota direksi memiliki kinerja yang lebih baik. Menurut Miaoui dalam IFC (2013), beberapa penelitian di bidang bisnis dan ekonomi menunjukkan hubungan erat antara kinerja perusahaan dengan semakin banyaknya perempuan yang menjadi anggota direksi. Sementara Shawver et al. dalam Sihite (2012) mengindikasikan bahwa akuntan 
perempuan memiliki kecenderungan yang lebih kecil untuk melakukan manajemen laba.

Beragam penelitian tersebut, meski sebagian hasilnya inkonsisten dan saling bertentangan, memiliki makna signifikan terutama jika mengingat fakta diskriminasi yang masih banyak dialami perempuan dalam bidang keuangan di berbagai negara (Demirguc-Kunt 2013). Analisis ILO pada 83 negara, juga menemukan bahwa perempuan rata-rata dibayar 10 hingga 30 persen lebih rendah daripada partner prianya (World Bank 2013).

Penelitian ini berkontribusi dengan mengafirmasikembali peran dan pengaruh keberadaan perempuan dalam jajaran anggota dewan perusahaan, yaitu gabungan anggota direksi dan komisaris, terutama terhadap praktik income smoothing.

Berdasarkan pemaparan di atas, permasalahan yang dirumuskan dalam penelitian ini adalah: 1) Apakah return on assets, net interest margin, debt to equity ratio secara simultan dan parsial mempengaruhi income smoothing?; 2) Apakah return on assets, net interest margin, debt to equity ratio secara simultan dan parsial mempengaruhi income smoothing dengan memperhitungkan proporsi perempuan dalam dewan perusahaan?

\section{Metode Penelitian}

Profitabilitas adalah salah satu indikator penting yang digunakan menilai perusahaan dan mempengaruhi investor dalam pengambilan keputusan. Sedangkan ROA mengukur kemampuan manajemen dalam menghasilkan laba dengan memanfaatkan aktiva yang digunakan dalam kegiatan operasi (Setiawan 2012). Hilda dalam Sihite (2012) menyimpulkan bahwa laki-laki pada umumnya bersifat lebih individualis, tegas, dengan rasa percaya diri tinggi dan menguasai pekerjaan dibandingkan lawan jenisnya. Sedangkan perempuan cenderung lebih perhatian kepada orang lain, penurut, dan lebih mementingkan perasaan. Perbedaan ini mendorong karyawan perempuan untuk bersikap dan berlaku lebih selaras dengan kebijakan dan peraturan perusahaan. Hal ini juga didukung Dunstan et al. (2011) yang menyimpulkan bahwa keragaman gender dalam dewan perusahaan memiliki implikasi penting pada pembuat regulasi perusahaan. Fuentes-Medina et al. (2013) menemukan bahwa ROA berkaitan dengan reputasi perusahaan. Sedangkan reputasi perusahaan dipengaruhi oleh jumlah atau bobot perempuan pada dewan perusahaan. Dengan demikian, eksekutif perempuan pun diyakini akan menghindari penerapan praktik income smoothing.

H1a: Return on assets berpengaruh signifikan terhadap income smoothing.

H1b: Semakin tinggi proporsi perempuan dalam dewan perusahaan akan memperlemah pengaruh return on assets terhadap income smoothing.

NIM adalah rasio antara pendapatan bunga bersih terhadap rata-rata aktiva produktif. Menurunnya rasio ini menunjukkan bahwa pendapatan bunga atas aktiva produktif yang dikelola bank juga menurun sehingga membawa kemungkinan suatu bank dalam kondisi bermasalah (Sari 2012). Dalam peran manajemen, manajer perempuan cenderung menyeimbangkan tingkat risk-taking dengan menghindari risiko (risk-averse) dibandingkan laki-laki (Ferrary dalam Sihite 2012). Meskipun demikian, 
Schwizer et al. (2012) tidak menemukan hubungan jumlah perempuan dalam dewan perusahaan dengan risiko perusahaan.

$\mathrm{H} 2 \mathrm{a}$ : Net interest margin berpengaruh signifikan terhadap income smoothing.

$\mathrm{H} 2 \mathrm{~b}$ : Semakin tinggi proporsi perempuan dalam dewan perusahaan akan memperlemah pengaruh net interest margin terhadap income smoothing.

Wulandari (2013) menyatakan bahwa financial leverage yang dapat diukur dengan debt to equity ratio menunjukkan proporsi penggunaan utang yang digunakan untuk membiayai investasinya. Berdasarkan debt covenant hypothesis dalam teori akuntansi positif, semakin besar rasio leverage perusahaan, maka manajer cenderung melakukan income smoothing dengan tujuan agar terhindar dari ketentuan-ketentuan yang termaktub dalam perjanjian hutang. Meyer dan Levy dalam Jamilah et al. (2007) menyatakan laki-laki cenderung tidak menggunakan seluruh informasi yang tersedia sehingga keputusan yang diambil kurang komprehensif. Sedangkan perempuan mengolah informasi lebih teliti dengan menggunakan informasi yang lebih lengkap dan mengevaluasinya kembali. Fuentes-Medina et al. (2013) menyimpulkan bahwa jumlah perempuan dalam dewan perusahaan berhubungan dengan reputasi perusahaan. Karena proporsi utang terhadap ekuitas akan berpengaruh terhadap reputasi perusahaan, maka dapat dirumuskan hipotesis berikutnya:

H3a: Debt to equity ratio berpengaruh signifikan terhadap income smoothing.

$\mathrm{H} 3 \mathrm{~b}$ : Semakin tinggi proporsi perempuan dalam dewan perusahaan akan memperlemah pengaruh debt to equity ratio terhadap income smoothing.

Byoun et al. (2011) menyimpulkan bahwa perusahaan dengan dewan perusahaan yang beragam berkecenderungan untuk membayarkan dividen lebih besar dibandingkan dengan perusahaan yang dewan perusahaannya tidak beragam. Temuan mereka juga konsisten dengan argumen bahwa dewan perusahaan yang beragam meningkatkan fungsi pengawasan direksi serta kebebasan direksi, yang pada akhirnya akan memberi manfaat para pemegang saham. Dengan memperhatikan argumentasiargumentasi sebelumnya, dapat diajukan hipotesis pengaruh variabel-variabel independen secara simultan terhadap variabel dependen sebagai berikut:

H4a: Return on assets, net interest margin, dan debt to equity ratio, secara simultan berpengaruh terhadap income smoothing.

$\mathrm{H} 4 \mathrm{~b}$ : Proporsi perempuan dalam dewan perusahaan mempengaruhi hubungan antara return on assets, net interest margin, dan debt to equity ratio terhadap income smoothing.

Berdasarkan landasan teori dan permasalahan yang dikemukakan, kerangka pemikiran teoritis dapat dituangkan seperti pada Gambar 1.

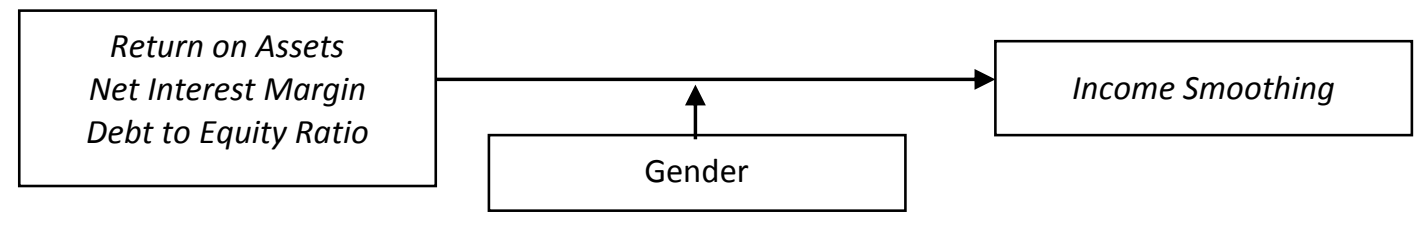

Gambar 1. Model kerangka pemikiran

Penelitian ini menggunakan data sekunder berupa laporan keuangan tahunan yang diterbitkan oleh emiten perbankan yang telah tercatat dan tidak pernah tidak 
tercatat pada Bursa Efek Indonesia (BEI) selama kurun waktu 2008-2012. Metode pemilihan sampel dilakukan secara purposive sampling, sehingga diperoleh sampel penelitian sebanyak 26 bank. Studi literatur pendukung penelitian didapat dari berbagai sumber seperti internet, penelitian terdahulu, jurnal dan buku.

Variabel dependen dalam penelitian ini adalah income smoothing. Untuk mengidentifikasi perusahaan yang melakukan perataan laba, digunakanlah Indeks Eckel dengan rumusan sebagai berikut:

$$
\text { Indeks Eckel }\left(\text { Eckel 1981) }=\frac{C V \Delta I}{C V \Delta S}\right.
$$

dimana:

$\mathrm{CV} \Delta \mathrm{I}=$ Koefisien variasi untuk perubahan laba

$\mathrm{CV} \Delta \mathrm{S}=$ Koefisien variasi untuk perubahan penjualan

$\mathrm{CV} \Delta \mathrm{I}$ dan $\mathrm{CV} \Delta \mathrm{S}$ dapat dihitung sebagai berikut :

$\mathrm{CV} \Delta \mathrm{I}$ dan $\mathrm{CV} \Delta \mathrm{S}=\frac{\text { Variance }}{\text { ExpectedValue }}$ Atau CV $\Delta \mathrm{I}$ dan $\mathrm{CV} \Delta \mathrm{S}=\overline{\overline{(\Delta x-\Delta X)^{2}}}: \Delta \mathrm{X} \ldots \ldots$

dimana:

$\Delta \mathrm{x}=$ Perubahan penghasilan bersih/laba (I) atau penjualan (S) antara tahun $\mathrm{n}-1$

$\Delta \mathrm{X}=$ Rata-rata perubahan penghasilan bersih/laba (I) atau penjualan (S) antara tahun $\mathrm{n}-1$

$\mathrm{n} \quad=$ Banyaknya tahun yang diamati

Ketentuan: Indeks Eckel untuk perusahaan bukan perata laba adalah $\geq 1$, sedangkan untuk perusahaan perata laba adalah $<1$.

Variabel independen dalam penelitian ini adalah ROA yang menunjukkan kemampuan perusahaan dalam menggunakan aktiva secara produktif, NIM yang menunjukkan kemampuan perbankan mengelola aktiva produktifnya dalam menghasilkan pendapatan bunga bersih, dan DER yang menunjukkan besarnya modal yang berasal dari pinjaman dan dipergunakan untuk membiayai investasi dan operasional perusahaan.

Variabel moderator adalah variabel independen yang dapat memperkuat atau memperlemah hubungan antara variabel independen dengan variabel dependen (Ghozali 2011). Variabel moderator dalam penelitian ini adalah gender yang merupakan proporsi perempuan dalam dewan perusahaan dibandingkan dengan jumlah keseluruhan anggota dewan perusahaan, yang merupakan gabungan antara direksi dan komisaris.

Metode analisis data yang digunakan dalam penelitian ini adalah analisis kuantitatif dengan menggunakan alat analisis SPSS berupa perhitungan statistik. Uji asumsi klasik dilakukan untuk mengetahui apakah model regresi benar menunjukkan hubungan yang signifikan dan representative (Ghozali 2011). Uji asumsi klasik yang digunakan dalam penelitian ini meliputi: Uji normalitas dengan menggunakan 
Kolmogorov-Smirnov (K-S). Uji multikolinieritas dengan nilai tolerance $\geq 0.1$ dan Variance Inflation Factor (VIF) $\leq 10$ maka tidak terjadi multikolinieritas. Uji autokorelasi dilakukan dengan uji Durbin-Watson, apabila Du $<$ Dhit $<(4-D u)$ maka tidak terjadi autokorelasi.

Uji Hipotesis dilakukan dengan metode analisis regresi linier berganda yang menganalisis hubungan antara dua atau lebih variabel independen terhadap satu variabel dependen, dan metode analisis Moderated Regression Analysis (MRA) atau uji interaksi merupakan aplikasi khusus regresi linier berganda di mana dalam persamaan regresinya mengandung unsur interaksi (perkalian dua atau lebih variabel independen). Jika variabel gender merupakan variabel moderator, maka koefisien $\beta$ harus signifikan pada tingkat signifikansi yang ditentukan. Dalam pengujian hipotesis dilakukan pada uji F (simultan) dan uji T (individu).

\section{Hasil dan Pembahasan}

\section{III.1. Hasil Pengujian Income Smoothing}

Langkah pertama dalam penelitian ini adalah melakukan perhitungan Indeks Eckel untuk mengklasifikasikan status perusahaan menjadi perusahaan perata laba dan perusahaan bukan perata laba. Data tersebut terdapat pada Tabel 1.

Tabel 1. Perusahaan perata laba per tahun

\begin{tabular}{cccccc}
\hline No & $\mathbf{2 0 0 8}$ & $\mathbf{2 0 0 9}$ & $\mathbf{2 0 1 0}$ & $\mathbf{2 0 1 1}$ & $\mathbf{2 0 1 2}$ \\
\hline 1 & BABP & BBCA & BBCA & AGRO & BBRI \\
2 & BACA & BBRI & BCIC & BACA & BCIC \\
3 & BBNI & BCIC & BMRI & BBCA & BMRI \\
4 & BBNP & BNII & BNGA & BBNP & BNBA \\
5 & BCIC & BNLI & BNII & BBRI & BNGA \\
6 & BDMN & BSWD & MCOR & BCIC & BNII \\
7 & BNBA & INPC & NISP & BEKS & MAYA \\
8 & BNGA & PNBN & PNBN & BKSW & MEGA \\
9 & BNII & - & - & BMRI & SDRA \\
10 & BNLI & - & - & BNII & - \\
11 & INPC & - & - & BNLI & - \\
12 & PNBN & - & - & BSWD & - \\
13 & - & - & - & BVIC & - \\
14 & - & - & - & MEGA & - \\
\hline
\end{tabular}

Sumber: Laporan keuangan perbankan dari BEI (2014), diolah

Berdasarkan pengklasifikasian tersebut, diketahui bahwa jumlah perusahaan perata laba pada tahun 2008 dan tahun 2011 jauh lebih banyak dibandingkan dengan tahun 2009, 2010, dan 2012.

Terjadinya income smoothing dapat dipicu oleh ketidakstabilan sistem keuangan akibat berbagai macam penyebab dan gejolak. Pada tahun 2008 sebanyak 12 dari 26 perusahaan diindikasikan melakukan income smoothing, akibat dampak krisis keuangan sebagai akibat kejatuhan bisnis kredit properti di Amerika Serikat yang berdampak besar pada perekonomian global, termasuk di kawasan Asia. Dampak 
terjadinya guncangan ekonomi mengakibatkan likuiditas perbankan semakin ketat dengan turunnya nilai tukar rupiah dari Rp 9466 menjadi Rp 11005 per dollar AS (BI 2014b) dan kenaikan inflasi dari 6.59\% per Desember 2007 meningkat hingga 11.06\% per Desember 2008 (BI 2014a). Padahal, bagi perbankan, masalah likuiditas lebih penting dibandingkan ukuran kredit macet atau Non Performing Loan (NPL).

Pada tahun 2011 sebanyak 14 dari 26 perusahaan diindikasikan melakukan income smoothing. Hal ini diperkirakan dipengaruhi oleh ketidakpastian akibat krisis utang Eropa dan kekhawatiran terhadap prospek pemulihan perekonomian AS yang memicu gejolak di pasar keuangan dan pelemahan pertumbuhan ekonomi global tahun 2011. Di sektor keuangan, penarikan modal luar negeri oleh sebagian investor pada semester II tahun 2011 memberikan tekanan pada nilai tukar rupiah, imbal hasil obligasi Pemerintah, dan harga saham, serta tingkat inflasi 6.96\% per Desember 2010 meningkat menjadi 7.02\% di awal tahun 2011 (BI 2014a) dan nilai tukar dari Rp 9.036 menjadi Rp 9113 per dollar (BI 2014b).

Kondisi perekonomian tersebut mengakibatkan menurunnya ekspor dan berdampak pada kinerja keuangan para nasabah pengguna pembiayaan perbankan dan lembaga keuangan lainnya. Perusahaan harus tetap membayar pinjaman pada kreditur, sehingga meningkatkan probabilitas gagal bayar yang mengakibatkan berkurangnya modal perbankan sebagai pihak kreditur. Risiko yang dihadapi perbankan dengan kondisi tersebut adalah potensi meningkatnya NPL.

Bagi industri perbankan, depresiasi rupiah dan tekanan likuiditas juga memicu persaingan ketat dalam memperoleh pendanaan, sehingga meningkatkan cost of fund dan mengurangi peraihan margin laba. Dengan alasan bahwa laba menjadi perhatian dalam menaksir kinerja dan pertanggungjawaban manajemen dalam pengelolaan dana yang telah dipercayakan, maka manajemen perbankan akan terdorong untuk melakukan praktik income smoothing.

Berdasarkan Tabel 1, juga diketahui bahwa terdapat dua perusahaan dengan status perusahaan perata laba berturut-turut dalam kurun waktu 5 tahun, yaitu Bank Mutiara Tbk (BCIC) dan Bank Internasional Indonesia Tbk (BNII). Hal ini disebabkan oleh kondisi keuangan perusahaan yang tidak stabil selama periode tersebut. Terbukti dari laporan dewan perusahaan kepada para pemegang saham bahwa pada tahun 2008, BCIC yang awalnya bernama Bank Century mengalami gagal kliring akibat belum menerapkan prinsip Good Corporate Governance (GCG), tidak prudent dan juga gagal mengelola risiko sehingga Lembaga Penjamin Simpanan (LPS) harus mengambil alih sebagai langkah penyelamatan demi menjaga stabilitas industri perbankan nasional.

Sedangkan kendala yang dialami oleh BNII yaitu bank mencatat kerugian konsolidasian sebesar Rp 41 miliar di tahun 2009, yang merupakan penurunan dari laba bersih tahun 2008. Penurunan ini terutama disebabkan karena pada tahun 2008 bank memperoleh pendapatan non operasional dari pelepasan dan pejualan asset kantor luar negeri yang tidak beroperasi lagi serta beberapa investasi tertentu.

\section{III.2. Uji Statistik Deskriptif}

Langkah selanjutnya dalam penelitian ini adalah pengujian asumsi klasik dan pengujian hipotesis antara variabel dependen dengan variabel independen pada 51 sampel yang berstatus sebagai perusahaan perata laba. Namun, hasil analisis awal 
menunjukkan adanya pencilan, yakni data yang menyimpang terlalu jauh dari yang lain, sehingga harus dikeluarkan dari model penelitian sebanyak 6 data. Jadi, dalam pengolahan data, akan digunakan sebanyak 45 sampel yang memenuhi syarat pengujian. Deskripsi statistik berguna untuk mengetahui karakter sampel yang digunakan dalam penelitian.

Tabel 2. Hasil uji statistik deskriptif

\begin{tabular}{lccccc}
\hline \multicolumn{7}{c}{ Descriptive Statistics } \\
\hline & N & Minimum & Maximum & Mean & $\begin{array}{c}\text { Std. } \\
\text { Deviation }\end{array}$ \\
\hline ROA & 45 & -.025 & .035 & .01411 & .010618 \\
NIM & 45 & .008 & .111 & .05527 & .020124 \\
DER & 45 & 3.026 & 15.024 & 9.14560 & 2.608494 \\
INCOME_SMOOTHING & 45 & -1.845 & .974 & .34742 & .601024 \\
GENDER & 45 & .000 & .375 & .12120 & .094398 \\
Valid N (listwise) & 45 & & & & \\
\hline
\end{tabular}

Sumber: Data diolah (2014)

Dari Tabel 2 dapat diketahui jumlah sampel yang diteliti sebanyak 45, dengan tiga variabel indepeden, satu variabel dependen, dan satu variabel moderator.

1. Variabel ROA memiliki nilai minimum -0.025 dan maksimum 0.035 , menunjukkan bahwa ada emiten yang memiliki total laba bersih relatif kecil dengan nilai ROA yang negatif. Sementara nilai mean 0.014 dan standar deviasi sebesar 0.011 , artinya tidak ada perbedaan yang signifikan antar nilai mean dengan nilai standar deviasi.

2. Variabel NIM memiliki nilai minimum 0.008 dan maksimum 0.111 , menunjukkan bahwa ada emiten yang memiliki total pendapatan bunga bersih relatif kecil. Sementara nilai mean 0.055 dan standar deviasi sebesar 0.020, artinya terlalu besar penyimpangan terjadi dari rata-rata yang dimiliki oleh emiten.

3. Variabel DER memiliki nilai minimum 3.026 dan maksimum 15.024, menunjukkan bahwa ada emiten yang memiliki nilai ekuitas relatif kecil. Sementara nilai mean 9.146 dan standar deviasi sebesar 2.608, artinya terlalu besar penyimpangan terjadi dari rata-rata yang dimiliki oleh masing-masing emiten.

4. Variabel income smoothing memiliki nilai minimum -1.845 dan maksimum 0.974 , menunjukkan bahwa ada emiten yang diindikasikan melakukan income smoothing. Sementara nilai mean 0.347 dan standar deviasi sebesar 0.601 , artinya terlalu besar penyimpangan terjadi dari rata-rata yang dimiliki emiten.

5. Variabel gender memiliki nilai minimum 0.000 dan maksimum 0.375 , menunjukkan bahwa ada emiten yang tidak memposisikan perempuan dalam dewan perusahaan. Sementara nilai mean 0.121 dan standar deviasi sebesar 0.094, artinya tidak ada perbedaan yang signifikan antara nilai mean dengan nilai standar deviasi.

\section{III.3. Uji Asumsi Klasik}

Untuk mendapatkan nilai penduga parameter yang tidak bias perlu dilakukan pengujian untuk mengetahui apakah model regresi yang dihasilkan memenuhi persyaratan asumsi klasik. Pengujian asumsi klasik tersebut terdiri dari uji normalitas, uji multikolinieritas, dan uji autokorelasi. 
114|Kusumaningrostati, Mutasowifin - Analisis Pengaruh Faktor-Faktor

Tabel 3. Hasil uji normalitas Kolmogorov-Smirnov

\begin{tabular}{ccc}
\hline Asymp. Sig. (2-tailed) & Keterangan & Keputusan \\
\hline 0.998 & $\mathrm{p}>0.05$ & Data Normal \\
\hline
\end{tabular}

Sumber: Data diolah (2014)

Hasil pengujian normalitas dengan uji statistik Kolmogorov-Smirnov terhadap nilai residual menghasilkan 0.998 menunjukkan bahwa residual terdistribusi secara normal.

Tabel 4. Hasil uji multikolinieritas variabel independen

\begin{tabular}{cccc}
\hline Variabel & Tolerance & VIF & Keputusan \\
\hline ROA & 0.953 & 1.049 & \\
NIM & 0.968 & 1.033 & Tidak Terjadi Multikolinieritas \\
DER & 0.924 & 1.082 & \\
\hline
\end{tabular}

Sumber: Data diolah (2014)

Hasil pengujian multikolinieritas menunjukkan bahwa nilai VIF tidak melebihi 10 dan nilai tolerance tidak kurang dari 0.10. Hal ini menjelaskan kembali dari hasil korelasi antar variabel independen tidak ada korelasi yang cukup serius.

Tabel 5. Hasil uji autokorelasi Durbin Watson

\begin{tabular}{cccc}
\hline Du & Dw & 4-du & Keputusan \\
\hline 1.6662 & 1.983 & 2.3338 & Tidak Terjadi Autokorelasi \\
\hline
\end{tabular}

Sumber: Data diolah (2014)

Hasil pengujian autokorelasi menunjukkan bahwa besarnya nilai Durbin Watson (DW) sebesar 1.983. Oleh karena itu nilai DW hitung $>$ du dan kurang dari 4-du (1.6662 $<1.983<2.3338$ ), maka dapat disimpulkan tidak terdapat autokorelasi. Jadi secara keseluruhan dapat disimpulkan bahwa model regresi memenuhi syarat uji asumsi klasik. Langkah selanjutnya adalah menganalisis hasil regresi.

\section{III.4. Uji Hipotesis Regresi Linier Berganda dan Model Regresi Moderasi}

Pengujian hipotesis dilakukan melalui pengujian regresi linier berganda untuk mengidentifikasi pengaruh ROA, NIM, dan DER terhadap Income Smoothing. Selanjutnya dilakukan pengujian model regresi moderasi untuk mengidentifikasi pengaruh variabel gender sebagai moderator pada ROA, NIM, dan DER terhadap Income Smoothing.

1. Uji Koefisien Determinasi Regresi Linier Berganda

Nilai koefisien determinasi menguji kekuatan dari model regresi dalam memprediksi. Semakin besar nilai koefisien determinasi, akan semakin besar kemampuan variabel bebas dalam menjelaskan variabel terikat.

Tabel 6. Hasil uji koefisien determinasi regresi linier berganda

\begin{tabular}{ccc}
\hline Variabel Dependen & Variabel Independen & R Square \\
\hline INCOME SMOOTHING & ROA,NIM,DER & 0,337 \\
\hline
\end{tabular}

Sumber: Data diolah (2014) 
Besarnya nilai $R$ Square 0.337 yang berarti 33.7\% variabel income smoothing dapat dijelaskan oleh variabel ROA, NIM dan DER dalam penelitian ini. Selebihnya $66.3 \%$ dijelaskan oleh varibel lain yang tidak dimasukkan dalam model regresi.

\section{Uji Simultan dan Uji Parsial Regresi Linier Berganda}

Uji pengaruh simultan digunakan untuk mengetahui apakah variabel independen secara bersama-sama atau simultan mempengaruhi variabel dependen. Sedangkan Uji parsial digunakan untuk mengetahui pengaruh masing-masing variabel independen terhadap variabel dependen.

Tabel 7. Hasil pengujian secara simultan dan parsial regresi linier berganda

\begin{tabular}{ccccc}
\hline Pengujian & Variabel & Sig. & Keterangan & Hipotesis \\
\hline Uji-F & ROA,NIM,DER & 0.001 & $\mathrm{p}<0.05$ & H4a diterima \\
Uji-T & ROA & 0.011 & $\mathrm{p}<0.05$ & H1a diterima \\
Uji-T & NIM & 0.033 & $\mathrm{p}<0.05$ & H2a diterima \\
Uji-T & DER & 0.004 & $\mathrm{p}<0.05$ & H3a diterima \\
\hline
\end{tabular}

Sumber: Data diolah (2014)

Hasil uji $\mathrm{F}$ menunjukkan signifikansi sebesar 0.001 yang berarti model regresi dapat memprediksi besarnya pengaruh variabel ROA, NIM dan DER secara simultan terhadap variabel income smoothing. Maka dapat disimpulkan bahwa hipotesis $\mathrm{H} 4 \mathrm{a}$ diterima, di mana return on assets, net interest margin, dan debt to equity ratiosecara simultan berpengaruh terhadap income smoothing.

Hasil uji T atau secara parsial menunjukkan bahwa hipotesis $\mathrm{H} 1 \mathrm{a}, \mathrm{H} 2 \mathrm{a}$, dan $\mathrm{H} 3 \mathrm{a}$ diterima. Sehingga dapat disimpulkan bahwa return on assets, net interest margin, dan debt to equity ratio secara parsial berpengaruh signifikan terhadap income smoothing.

Berdasarkan pengujian regresi ROA dengan income smoothing menghasilkan pengaruh negatif dan $p$-value sebesar 0.011 yang berarti berpengaruh signifikan terhadap income smoothing. Hasil penelitian ini konsisten dengan Atarwaman (2011), Wijaya (2011) dan Bestivano (2013) bahwa variabel return on assets mempengaruhi income smoothing. Namun, hasil yang berbeda ditunjukkan oleh Widaryanti (2009), Kurniawan (2012), Setiawan (2012) dan Masodah (2007). Pengaruh yang negatif menjelaskan bahwa, jika rasio ROA naik, maka manajemen akan mengurangi tindakan income smoothing. Berdasarkan bonus plan hypothesis dalam teori akuntansi positif menurut Watt dan Zimmerman dalam Rahmawati (2012), jika perusahaan merencanakan bonus berdasarkan net income, perusahaan tersebut akan memilih prosedur akuntansi yang menggeser pelaporan laba masa datang ke periode sekarang. Dapat disimpulkan, rasio ROA yang tinggi menggambarkan kinerja manajemen yang baik, sehingga dapat meningkatkan bonus bagi manajemen.

Pengujian regresi NIM dengan income smoothing menghasilkan pengaruh positif dan $p$-value sebesar 0.033 yang berarti konsisten dengan Sari (2012) dan Astuti (2013) yang menunjukkan bahwa net interest margin berpengaruh signifikan terhadap income smoothing. Pengaruh positif menjelaskan bahwa, jika rasio NIM naik, maka manajemen akan melakukan tindakan income smoothing. Berdasarkan political cost hypothesis menurut Watt dan Zimmerman dalam Rahmawati (2012), perusahaan cenderung untuk menangguhkan laba sekarang ke periode mendatang untuk 
menghindari tekanan politik. Dapat disimpulkan, rasio NIM yang tinggi menggambarkan pendapatan net income meningkat dan mengakibatkan kenaikan pajak yang harus dibayarkan. Dengan demikian, manajemen terdorong melakukan income smoothing dengan menangguhkan pendapatan net income saat ini ke periode berikutnya untuk menghindari kenaikan pajak.

Pengujian regresi DER dengan income smoothing menghasilkan pengaruh negatif dan $p$-value sebesar 0.004, konsisten dengan penelitian Wulandari (2013) dan Masodah (2007) di mana debt to equity ratio berpengaruh signifikan terhadap income smoothing. Namun, hasil ini berlainan Widaryanti (2009), Kurniawan (2012) dan Bestivano (2013). Pengaruh negatif menjelaskan bahwa, jika rasio DER naik, manajemen akan mengurangi income smoothing. Hasil pengujian ini berbeda dengan debt covenant hypothesis menurut Watt dan Zimmerman dalam Rahmawati (2012), dimana perusahaan cenderung menurunkan rasio utang/ekuitas dengan cara meningkatkan laba sekarang dengan menggeser laba dari periode mendatang. Ditinjau dari rasio DER yang digunakan untuk mengukur seberapa jauh perusahaan dibiayai oleh hutang, jika rasio DER tinggi akan meningkatkan risiko yang ditanggung oleh debitur dan kreditur. Untuk itu dilakukan pengawasan yang ketat, sehingga dalam menjaga reputasi perusahaan akan menurunkan motivasi manajemen untuk melakukan income smoothing.

\section{Uji Koefisien Determinasi Model Regresi Moderasi}

Semakin besar nilai koefisien determinasi, maka semakin besar kemampuan variabel independen dan variabel moderator dalam menjelaskan variabel dependen.

Tabel 8. Hasil uji koefisien determinasi model regresi moderasi

\begin{tabular}{ccc}
\hline Variabel Dependen & Variabel Independen & R Square \\
\hline INCOME SMOOTHING & $\begin{array}{c}\text { ROA, NIM, DER, INTERAKSIROA, } \\
\text { INTERAKSINIM,I NTERAKSIDER }\end{array}$ & 0.583 \\
\hline
\end{tabular}

Sumber : Data diolah (2014)

Hasil pengujian koefisien determinasi menunjukkan nilai $R$ Square sebesar 0.583 yang berarti variabilitas income smoothing yang dapat dijelaskan oleh variabel independen dengan variabel moderator sekitar $58.3 \%$ dan selebihnya $41.7 \%$ dijelaskan oleh variabel lain di luar model ini.

4. Uji Simultan dan Uji Parsial Model Regresi Moderasi

Uji pengaruh simultan digunakan untuk mengetahui apakah variabel independen dan moderator secara simultan mempengaruhi variabel dependen. Sedangkan Uji parsial digunakan untuk mengetahui pengaruh variabel moderator pada masingmasing variabel independen terhadap variabel dependen.

Tabel 9. Hasil pengujian secara simultan dan parsial model regresi moderasi

\begin{tabular}{ccccc}
\hline Pengujian & Variabel & Sig. & Keterangan & Hipotesis \\
\hline Uji-F & $\begin{array}{l}\text { ROA,NIM,DER, } \\
\text { INTERAKSIROA, } \\
\text { INTERAKSINIM, } \\
\text { INTERAKSIDER }\end{array}$ & 0.000 & $\mathrm{p}<0.05$ & H4b diterima \\
\hline
\end{tabular}


Lanjutan Tabel 9.

\begin{tabular}{ccccc} 
Pengujian & Variabel & Sig. & Keterangan & Hipotesis \\
Uji-T & INTERAKSIROA & 0.000 & $\mathrm{p}<0.05$ & H1b diterima \\
Uji-T & INTERAKSINIM & 0.002 & $\mathrm{p}<0.05$ & H2b diterima \\
Uji-T & INTERAKSIDER & 0.736 & $\mathrm{p}>0.05$ & H3b ditolak \\
\hline
\end{tabular}

Sumber : Data diolah (2014)

Hasil uji $F$ menunjukkan signifikansi 0.000 yang menunjukkan bahwa $\mathrm{H} 4 \mathrm{~b}$ diterima, yaitu proporsi perempuan dalam dewan perusahaan mempengaruhi hubungan antara return on assets, net interest margin, dan debt to equity ratio terhadap income smoothing.

Hasil pengujian secara individu menunjukkan bahwa gender sebagai variabel moderator yang dijelaskan dengan proporsi perempuan dibandingkan seluruh anggota dewan perusahaan terbukti signifikan mempengaruhi ROA dan NIM terhadap income smoothing. Temuan ini konsisten dengan hasil pengujian regresi sebelumnya bahwa variabel ROA dan NIM berpengaruh terhadap income smoothing, sehingga dengan penambahan variabel gender, maka perlu diperhatikan proporsi perempuan dalam dewan perusahaan.

Interaksi antara variabel ROA dengan gender mengindikasikan bahwa efek moderator yang diberikan adalah positif. Sehingga dapat disimpulkan jika rasio ROA naik, adanya perempuan akan memperkuat tindakan manajemen untuk mengurangi income smoothing karena sikap karyawan perempuan yang cenderung berlaku selaras dengan kebijakan dan peraturan perusahaan. Hasil pengujian menunjukkan hipotesis H1b diterima yaitu semakin tinggi proporsi perempuan dalam dewan perusahaan akan memperlemah pengaruh return on assets terhadap income smoothing.

Interaksi antara variabel NIM dengan gender mengindikasikan bahwa efek moderator yang diberikan adalah negatif. Sehingga dapat disimpulkan jika rasio NIM naik, adanya perempuan akan memperlemah tindakan manajemen untuk melakukan income smoothing karena dalam manajemen, manajer perempuan cenderung menyeimbangkan risk-taking dengan lebih berhati-hati untuk menghindari risiko (riskaverse). Hasil pengujian menunjukkan hipotesis $\mathrm{H} 2 \mathrm{~b}$ diterima, yaitu semakin tinggi proporsi perempuan dalam dewan perusahaan akan memperlemah pengaruh net interest margin terhadap income smoothing.

Interaksi antara variabel DER dengan gender menunjukkan bahwa hipotesis $\mathrm{H} 3 \mathrm{~b}$ ditolak, yang berarti bahwa proporsi perempuan dalam dewan perusahaan tidak mempengaruhi pengambilan keputusan income smoothing melalui debt to equity ratio. Karena pada dasarnya manajer akan mengambil keputusan yang sama yaitu menghindari tindakan income smoothing, ketika rasio DER meningkat.

\section{III.5. Implikasi Manajerial}

Rekomendasi strategi yang dapat dihubungkan dengan temuan hasil penelitian ini bagi manajemen dalam pengelolaan laporan keuangan berdasarkan fungsi manajemen, di antaranya:

1. Planning, terkait dengan hasil penelitian yang menunjukkan bahwa semakin tinggi proporsi perempuan dalam dewan perusahaan akan memperlemah pengaruh return on assets dan net interest margin terhadap income smoothing, maka dengan 
menambah gender perempuan dalam komposisi dewan perusahaan memungkinkan untuk membantu menyediakan masukan dan arahan dengan keanekaragaman suara dan sudut pandang dalam pengambilan keputusan manajerial, sehingga dapat mengurangi terjadinya praktik income smoothing dalam perusahaan.

2. Organizing, dalam mengantisipasi kondisi sistem keuangan yang berfkluktuasi dan menghindari tindakan income smoothing, perlunya mengambil langkah dan kebijakan antisipasif dengan risk-management yang baik seperti menjaga kualitas asset melalui pengelolaan aktiva bermasalah.

3. Actuating, dalam penyajian laporan keuangan selain mengacu kepada Standar Akuntansi Keuangan (SAK), emiten perlu memperhatikan aturan-aturan regulator dan juga diharapkan para akuntan lebih peduli terhadap aspek etika dalam manajemen laba.

4. Controlling, bagi perbankan, memanipulasi laba dalam bentuk apapun mengakibatkan runtuhnya kepercayaan nasabah dan investor. Maka perlu menghindari tindakan income smoothing untuk meyakinkan pengguna laporan keuangan mengenai kebenaran informasi yang dilaporkan.

5. Bagi regulator, terkait dengan tindakan income smoothing, perlu melakukan pengawasan lebih intensif terhadap kondisi keuangan perusahaan yang mengalami ketidakstabilan untuk menghindari kerugian yang mungkin dialami oleh beberapa pihak atas tindakan yang hanya menguntungkan satu pihak.

6. Penelitian ini juga menunjukkan bahwa perempuan dapat memiliki dampak pada kinerja keuangan. Untuk itu, perlu dipertimbangkan regulasi yang mengatur jumlah minimum perempuan dalam posisi dewan perusahaan, meskipun Wahid (2011) menyimpulkan bahwa peningkatan efektivitas dewan perusahaan dapat dicapai hanya jika keragaman dalam dewan perusahaan dicapai secara sukarela, dan bukan dengan paksaan untuk mengikuti regulasi. Carter et al. (2010) juga tidak menemukan dampak positif maupun negatif dari inklusi perempuan dalam dewan perusahaan. Bukti yang mereka temukan menganjurkan agar penunjukan perempuan atau minoritas dalam dewan perusahaan haruslah berdasarkan kriteria dan bukan keinginan raihan kinerja masa mendatang. Hal ini selaras dengan Fuentes-Medina et al. (2013) bahwa kehadiran perempuan dalam dewan perusahaan saja tidaklah mempengaruhi reputasi perusahaan, namun yang lebih penting adalah bobot kehadirannya.

\section{Kesimpulan}

Hasil pengujian regresi secara simultan diperoleh bahwa model regresi dapat memprediksi besarnya pengaruh ketiga variabel independen dalam penelitian, yaitu Return on Assets (ROA), Net Interest Margin (NIM), dan Debt to Equity Ratio (DER) secara keseluruhan terhadap income smoothing. Hasil pengujian secara parsial menunjukkan bahwa income smoothing dipengaruhi oleh variabel Return On Assets (ROA), Net Interest Margin (NIM), dan Debt to Equity Ratio (DER).

Hasil pengujian secara simultan diperoleh bahwa interaksi antara variabel independen yaitu Return on Assets (ROA), Net Interest Margin (NPM), dan Debt to Equity Ratio (DER) dengan variabel moderator yaitu gender dapat mempengaruhi income smoothing. Hal ini menyimpulkan bahwa proporsi perempuan dalam dewan 
perusahaan mempengaruhi derajat kekuatan return on assets, net interest margin, dan debt to equity ratio terhadap income smoothing. Hasil pengujian secara parsial menunjukkan bahwa income smoothing dipengaruhi oleh interaksi antara variabel Return on Assets (ROA) dan Net Interest Margin (NIM) dengan variabel gender. Interaksi antara variabel Debt to Equity Ratio (DER) dengan variabel gender tidak berpengaruh signifikan terhadap income smoothing. Hal ini menyimpulkan bahwa proporsi perempuan dalam dewan perusahaan memperlemah pengaruh return on assets dan net interest margin terhadap income smoothing.

\section{Daftar Pustaka}

Astuti S. 2013. Pengaruh Return on Assets (ROA), Net Interest Margin (NIM), Leverage dan Ukuran Perusahaan terhadap Praktik Manajemen Laba di Bank Umum Syariah Periode 2008-2012 [skripsi]. Yogyakarta (ID): Universitas Islam Negeri Sunan Kalijaga.

Atarwaman RJD. 2011. Analisis Pengaruh Ukuran Perusahaan, Profitabilitas, dan Kepemilikan Manejerial terhadap Praktik Perataan Laba yang Dilakukan oleh Perusahaan Manufaktur pada Bursa Efek Indonesia (BEI). JIEA. 2(2):67-79.

[BI] Bank Indonesia (ID). 2014a. Data Inflasi [Internet]. [diunduh 2014 April 20]. Tersedia pada: http://www.bi.go.id/id/moneter/inflasi/data/Default.aspx.

[BI] Bank Indonesia (ID). 2014b. Informasi Kurs [Internet]. [diunduh 2014 April 20]. Tersedia pada: http://www.bi.go.id/id/moneter/informasi-kurs/transaksibi/Default.aspx.

Bestivano W. 2013. Pengaruh Ukuran Perusahaan, Umur Perusahaan, Profitabilitas, dan Leverage terhadap Perataan Laba pada Perusahaan yang Terdaftar di BEI [skripsi]. Padang (ID): Universitas Negeri Padang.

Bianco M, Ciavarella A, Signoretti R. 2013. Women on Corporate Boards in Italy. Questioni di Economia e Finanza (Occasional Papers). Number 174-June 2013.

Bolbol I. I. H. 2012. Board Characteristics and Dividend Payout of Malaysian Companies [tesis]. Malaysia (MY): University Utara Malaysia.

Byoun S, Chang K, Kim YS 2011. Does Corporate Board Diversity Affect Corporate Payout Policy? Working paper.

Carter DA, Simkins BJ, Simpson WG. 2003. Corporate Governance, Board Diversity, and Firm Value. Financial Review. 38: 33-53.

Carter DA, D'Souza F, Simkins BJ, Simpson WG. 2010. Corporate Governance: An International Review. 18(5): 396-414.

Colaco HMJ, Myers P, Nitkin MR. 2011. Pathways to Leadership: Board Independence, Diversity and the Emerging Pipeline in the United States for Women Directors. International Journal of Disclosure and Governance. 8(2): 122-147.

Darmadi S. 2011. Board Diversity and Firm Performance: the Indonesian Evidence. Corporate Ownership and Control. 8.

Demirguc-Kunt A, Klapper L, Singer D. 2013. Financial Inclusion and Legal Discrimination Against Women: Evidence from Developing Countries. Policy 
Research Working Paper 6416. The World Bank Development Research Group, Finance and Private Sector Development Team.

Djaddang S. 2010. Analisis Hubungan Perataan Laba (Income Smoothing) dengan Ekspektasi Laba Masa Depan Perusahaan Manufaktur yang Terdaftar di Bursa Efek Jakarta [Internet]. [diunduh 2013 Okt 2]. Tersedia pada: http://isa7695.wordpress.com/2010/07/26/analisis-hubungan-perataan-labaincome-smoothing-dengan-ekspektasi-laba-masa-depan-perusahaanmanufaktur-yang-terdaftar-di-bursa-efek-jakarta/.

Dunstan K, Keeper T, Truong TP, van Zijl T. 2011. The Influence of Board Structure on the Value of NZX Listed Firms and Its Association with Growth Options. Working Paper No. 76.

Dutta P. 2006. Gender Diversity in the Boardroom and Financial Performance of Commercial Bank: Evidence from Bangladesh. The Cost and Management. 34(6): 70-74.

Eckel N. 1981. The Income Smoothing Hypothesis Revisited. ABACUS [Internet]. [diunduh 2014 April1]; 17(1):28-40. Tersedia pada: http://onlinelibrary. wiley.com/doi/10.1111/i.1467-6281.1981.tb00099.x/abstract.

Fauzi F, Locke S. 2012. Board Structure, Ownership Structure and Firm Performance: A Study of New Zealand Listed Firms. Asia Academy of Management Journal of Accounting and Finance. 8(2): 43-67.

Fuentes-Medina ML, Morini-Marrero S, Verona-Martel MC. 2013. The Women's Role in Corporate Reputation: A Study of the Most Reputable Spanish Firms. Advanced Research in Scientific Areas. December, 2. -6.

Ghozali I. 2011. Aplikasi Analisis Multivariate dengan Program IBM SPSS 19 (ed.5). Semarang (ID): Badan Penerbit Universitas Diponegoro.

[IFC] International Finance Corporation. 2013. IFC Mendukung Perempuan di Jajaran Direksi Perusahaan di Indonesia [Internet]. [diunduh 2013 Okt 5]. Tersedia pada: http://www.worldbank.org/in/news/feature/2013/07/31/ifc-championingwomen-on-corporate-boards-in-indonesia.

Jamilah S, Fanani Z, Chandrarin G. 2007. Pengaruh Gender, Tekanan Ketaatan, dan Kompleksitas Tugas terhadap Audit Judgment. Simposium Nasional Akuntansi $X$. 26-28 Juli 2007. Makassar (ID): Unhas.

Kurniawan. 2012. Faktor-Faktor yang Berpengaruh terhadap Perataan Laba pada Perusahaan Manufaktur yang Terdaftar di Bursa Efek Indonesia [skripsi]. Surabaya (ID): Sekolah Tinggi Ilmu Perbanas.

Martin L, Scott JM, Roper S, Warren-Smith I. 2009. Board Gender Diversity and Performance in UK Companies. Working Paper No: MS_WPS_MAN_09_3

Masodah. 2007. Praktik Perataan Laba Sektor Industri Perbankan dan Lembaga Keuangan Lainnya dan Faktor yang Mempengaruhinya. Proceeding PESAT [Internet]. [diunduh 2014 April1];2:A16-A23. Tersedia pada: http://dosengo2blog.weebly.com/uploads/2/1/7/6/2176156/income_smoothing.pdf.

Pramono O. 2013. Analisis Pengaruh ROA, NPM, dan Size terhadap Praktik Perataan Laba (Studi Kasus pada Perusahaan Manufaktur yang Terdaftar di Bursa Efek Indonesia Periode 2007-2011). JI Mahasiswa Universitas Surabaya. 2(2):1-16. 
Rahmawati, Suparno Y, Qomariyah N. 2006. Pengaruh Asimetri Informasi terhadap Praktik Manajemen Laba pada Perusahaan Perbankan Public yang Terdaftar di Bursa Efek Jakarta. Simposium Nasional Akuntansi IX. 23-26 Agustus 2006. Padang (ID): UNS.

Rahmawati. 2012. Teori Akuntansi Keuangan. Yogyakarta (ID): Graha Ilmu.

Sari NSK. 2012. Pengaruh Kinerja Keuangan terhadap Manajemen Laba pada Perusahaan Perbankan Go Public tahun 2007-2011 [tesis]. Surabaya (ID): Universitas Negeri Surabaya.

Schwizer P, Soana M-G, Cucinelli D. 2012. The Relationship Between Board Diversity and Firm Performance: The Italian Evidence. Working paper. Department of Banking and Insurance, Faculty of Economics, University of Parma.

Setiawan I. 2012. Analisis Pengambilan Keputusan Perusahaan Manufaktur dalam Melakukan Praktik Perataan Laba [skripsi]. Semarang (ID): UNES.

Sihite RC. 2012. Pengaruh Gender pada Dewan Komisaris, Dewan Direksi, dan Dewan Audit terhadap Profitabilitas dan Kualitas Laba Perusahaan [skripsi]. Jakarta (ID): Universitas Indonesia.

Sulistyanto SH. 2008. Manajemen Laba. Jakarta (ID): Grasindo.

Ujunwa A, Okoyeuzu C, Nwakoby I. 2012. Corporate Board Diversity and Firm Performance: Evidence from Nigeria. Review of International Comparative Management. 13(4): 605-620.

Vania H, Supatmi. 2014. The Effect of Board Diversity Towards the Company Value of Financial Institutions in Indonesia. International Journal of Business and Management Invention. 3(4): 32-41.

Wahid AS. 2011. Director Heterogeneity and Its Impact on Board Effectiveness. Working Paper. Accounting Seminars : Spring 2011. Darden School of Business, University of Virginia.

Wellalage NH, Locke S. 2013. Woman on Board, Firm Financial Performance and Agency Costs. Asian Journal of Business Ethics. 2: 113-127.

Widaryanti. 2009. Analisis Perataan Laba dan Faktor-Faktor yang Mempengaruhi pada Perusahaan Manufaktur di Bursa Efek Indonesia. Jurnal Fokus Ekonomi 4(2):6077.

Wijaya I. 2011. Pengaruh Profitabilitas, Financial Leverage dan Pertumbuhan Perusahaan terhadap Propensity Income Smoothing pada Perusahaan Perbankan yang Terdaftar di Bursa Efek Indonesia [tesis]. Medan (ID): Universitas Sumatera Utara.

World Bank. 2013. Gender at Work: A Companion to the World Development Report on Jobs. World Bank Group Gender \& Development.

Wulandari. 2013. Analisis Faktor-Faktor yang Mempengaruhi Income Smoothing dan Pengaruhnya terhadap Nilai Perusahaan Manufaktur yang Listed di BursaEfek Indonesia periode 2008-2011 [skripsi]. Semarang (ID): Universias Diponegoro.

Yasser QR. 2012. Affects of Female Directors on Firms Performance in Pakistan. Modern Economy. 3: 817-825. 